\title{
Is MTHFD1 polymorphisms rs 2236225 (c.1958G >A) associated with the susceptibility of NSCL/P? A systematic review and
} meta-analysis [version 1; peer review: 1 approved, 1 approved with reservations]

\author{
Huaxiang Zhao' ${ }^{1}$, Jieni Zhang ${ }^{1}$, Mengqi Zhang ${ }^{1}$, Feng Deng ${ }^{2}$, Leilei Zheng ${ }^{3}$, \\ Hui Zheng ${ }^{1}$, Feng Chen ${ }^{4}$, Jiuxiang Lin ${ }^{1}$ \\ ${ }^{1}$ Department of Orthodontics, Peking University School and Hospital of Stomatology, Peking, 100081, China \\ 2Bybo Dental Group, Beijing, 100062, China \\ ${ }^{3}$ Department of Orthodontics, Affiliated Hospital of Stomatology, Chongqing Medical University, Chongqing, 401147, China \\ ${ }^{4}$ Laboratory Center, Peking University School and Hospital of Stomatology, Peking, 100081, China
}

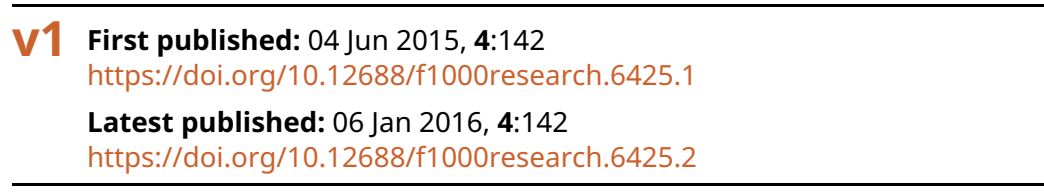

\section{Abstract}

Aims: To investigate the association between the methylenetetrahydrofolate dehydrogenase 1 (MTHFD1)

polymorphism rs 2236225 (c.1958G>A) and susceptibility to nonsyndromic cleft of the lip and/or palate (NSCL/P).

Methods: An extensive literature review has been conducted using PubMed, Web of Science, Cochrane Library, Google Scholar, the China National Knowledge Infrastructure (CNKI), and Wanfang Database for eligible researches. The terms for searching were "cleft lip OR cleft palate OR CLP OR CL/P OR oral facial cleft OR OFC" AND "methylenetetrahydrofolate dehydrogenase (NADP+ dependent) 1 OR methenyltetrahydrofolate cyclohydrolase formyltetrahydrofolate synthetase OR MTHFD1 OR MTHFD". Two independent researchers screened, evaluated and extracted the data of included studies. The pooled odds ratios (OR) with 95\% confidence intervals (95\% CI) were calculated by random effects model under five gene models.

Subgroup, sensitivity analysis and publication bias were also assessed. Results: Ten case-control studies have been included in the systematic review and eight studies have been considered for the meta-analysis. Overall, the MTHFD1 polymorphism rs2236225 and the risk of NSCL/P showed pooled OR (95\% CI) of 1.02 (0.86-1.21) under allelic model. A higher degree of heterogeneity was observed in Asian countries $\left(\mathrm{I}^{2}=75.6 \%\right)$ compared to non-Asian countries $\left(\mathrm{I}^{2}=48.9 \%\right)$. Similar consequence appeared in the subgroup of children $\left(\mathrm{I}^{2}=78.6 \%\right)$ compared with that of mothers $\left(\mathrm{I}^{2}=0.0 \%\right)$. There was no significant difference in the publication bias by the Begg's funnel plot $(P=0.711)$ and Egger's regression test $(P=0.746)$.

\section{Open Peer Review \\ Approval Status \\ 1 2 \\ version 2 \\ (revision) \\ 06 Jan 2016 \\ version 1 \\ 04 Jun 2015

$\checkmark$
view
$?$ \\ 1. Jingtan Su, University of Southern California, Los Angeles, USA \\ 2. Jose Suazo, University of Chile, Santiago, Chile}

Any reports and responses or comments on the article can be found at the end of the article. 
Conclusion: Our assessment suggested there was no significant association between the MTHFD1 polymorphism rs 2236225

(c.1958G>A) and the susceptibility to NSCL/P. Further investigations using a large sample size and a more advanced technique should be adopted to reach a more precise conclusion in the future.

Keywords

MTHFD1, Polymorphisms, NSCL/P susceptibility, Meta-analysis

Corresponding authors: Feng Chen (moleculecf@gmail.com), Jiuxiang Lin (jxlin@pku.edu.cn)

Competing interests: No competing interests were disclosed.

Grant information: This work was supported by grants 81200762 from National Natural Science Foundation of China; Program for the National Clinical Key Subject, Natural Science Foundation of China $(81271183,81470772)$; the Medical Scientific Research Project of Chongqing (20141013).

Copyright: $\odot 2015 \mathrm{Zhao} \mathrm{H}$ et al. This is an open access article distributed under the terms of the Creative Commons Attribution License, which permits unrestricted use, distribution, and reproduction in any medium, provided the original work is properly cited.

How to cite this article: Zhao $\mathrm{H}$, Zhang J, Zhang $M$ et al. Is MTHFD1 polymorphisms rs 2236225 (c.1958G>A) associated with the susceptibility of NSCL/P? A systematic review and meta-analysis [version 1; peer review: 1 approved, 1 approved with

reservations] F1000Research 2015, 4:142 https://doi.org/10.12688/f1000research.6425.1

First published: 04 Jun 2015, 4:142 https://doi.org/10.12688/f1000research.6425.1 


\section{Introduction}

Cleft of the lip and/or palate (CL/P) is one of the most common facial malformations ${ }^{1-3}$ and a societal burden, affecting the patient ability to eat and speak and influencing social integration ${ }^{4}$. Nonsyndromic CL/P, accounting for about $70 \%$ of CL/P, is considered closely related to genetic and environmental factors ${ }^{5}$. Recent studies suggested that using folic acid could reduce the rates of oral clefts $^{6,7}$ and single nucleotide polymorphisms of some genes such as MTHFR $^{8,9}$, MTR $^{40}$ and MTRR involved in the metabolism of folic acid have been associated to high risk of NSCL/P $\mathrm{P}^{8,9}$. Methylenetetrahydrofolate dehydrogenase 1 (MTHFD1), a key gene associated with three sequential enzymatic reactions in the metabolism of folic acid, might play a potential role in the risk of NSCL/P, especially the polymorphism rs2236225 (c.1958G $>A)^{10}$. Indeed, different observations that linked the polymorphism rs2236225 to the risk of NSCL/P have been reported ${ }^{11,12}$. The suggestion of a link between rs2236225 polymorphism and susceptibility to NSCL/P might be result of the limitations in sample size, different ethnic populations and other environmental factors. Therefore, we conducted a systematic review and meta-analysis of eligible case-control studies to reveal a more precise connection between the MTHFD1 polymorphism rs2236225 and the risk of NSCL/P.

\section{Materials and methods}

Identification of studies

A systematic search based on the principle of evidence-based medicine $^{13}$ was performed in PubMed, Web of Science, Cochrane Library, Google Scholar, China National Knowledge Infrastructure (CNKI) and WanFang Database. The final update was made on April 5th, 2015. In line with our knowledge background, the Medical Subject Headings (MESH) terms in PubMed and the known aliases of the genes of interests in the National Center of Biotechnology Information (NCBI), the following terms were used for searching: "cleft lip OR cleft palate OR CLP OR CL/P OR oral facial cleft OR OFC" AND "methylenetetrahydrofolate dehydrogenase (NADP+ dependent) 1 OR methenyltetrahydrofolate cyclohydrolase formyltetrahydrofolate synthetase OR MTHFD1 OR MTHFD", which were slightly adjusted to optimize search results (Table S1; PubMed). We didn't limit the search depending on publication types, data and language. Of course, the review of the published literature was examined carefully and manual search was conducted to avoid missing potential data. Two of the authors (Huaxiang Zhao and Mengqi Zhang) were in charge of the search independently and a third author (Jieni Zhang) conducted a random inspection.

\section{Inclusion and exclusion criteria}

Researches included in our systematic review and meta-analysis meet the following criteria: (1) evaluating the association between the NSCL/P and MTHFD1 polymorphism rs2236225, (2) focusing on humans, (3) case-control studies. Exclusion criteria were: (1) no association between NSCL/P and MTFHD1, (2) not focusing on humans but animal models or in vitro studies, (3) duplication of previous researches, (4) not original literature such as reviews, meta-analyses, comments and editorials.

\section{Data collection}

Data from eligible studies were extracted by two independent researchers (Huaxiang Zhao and Mengqi Zhang) in accordance with the inclusion and exclusion criteria. In case of any discrepancies, the third chief author (Feng Chen) would make a further investigation or bring it into a group-discussion. A special table was used for collecting information from the selected articles and the following entries were recorded: authors (year), country, location of geography, subjects, methods for genotyping, sample size of cases/controls, descriptions of samples rolled in the study, $\mathrm{P}$ for HWE (Hardy-Weinberg equilibrium) of control group, whether included in the meta-analysis or not.

\section{Methodological quality assessment}

A methodological quality assessment adapted from previous studies $^{14-16}$ was carried on included studies (Table S2). Cases, source of controls, sample sizes and Hardy-Weinberg equilibrium (HWE) were considered as important aspects in this systematic review.

\section{Statistical analysis}

The PRISMA checklist (Supplementary material S3) was used as a protocol in our meta-analysis ${ }^{17}$. Odd ratios (ORs) and $95 \%$ confidence intervals (CIs) were calculated to estimate the association between the susceptibility to NSCL/P and MTHFD1. Five genetic models were used in the process of pooling the OR and $95 \%$ CIs: allelic comparison (A versus $G$ ), heterozygote model (AG versus GG), homozygote model (AA versus GG), dominant model (AA + $A G$ versus $G G$ ), recessive model (AA versus $A G+G G$ ). The significance of the pooled effects was determined by Z-test with $\mathrm{P}$ value less than 0.05 . The Q-statistic and the $\mathrm{I}^{2}$ test were used to evaluated; $\mathrm{P}<0.05$ in Q statistic or $\mathrm{I}^{2}>50 \%{ }^{18,19}$, would indicate a significant heterogeneity. When $\mathrm{P}>0.05$ in $\mathrm{Q}$ statistic or $\mathrm{I}^{2}<50 \%$, the fixed pooling model (Mantel-Haenszel) was conducted; if not, the random pooling model (M-H heterogeneity) was used. We also carried subgroup analyses in which different subjects (mothers or children), location of geography (non-Asian countries or Asian countries) were considered potential source of heterogeneity. A sensitivity analysis was conducted by omitting each study in turn to evaluate the single study's influence on the overall estimation. We used Begg's funnel plot and Egger's linear regression test to find out the publication bias of the included studies ${ }^{20-22}$. The studies with disequilibrium of HWE among control group were added into a supplementary metaanalysis as described previously ${ }^{23}$. Meanwhile, as for the studies included but not carried into the meta-analysis, to achieve a qualitative analysis we adopted a method described by others ${ }^{24}$. Results were considered significant when $\mathrm{P}<0.05$. Stata 12.0 (Stata Corp, College Station, TX, USA) was used for the analysis. 


\section{Results}

Data retrieval

A total of 251 articles resulted from the search described above (PubMed: 86, Web of Science: 8, Google Scholar: 135, Cochrane Library: 0, CNKI: 18, Wanfang: 4). After being imported into EndNote X6 software (Thomson Corporation, Stamford), a screening process was conducted among 102 articles- that is, duplicates were removed using the 'Discard Duplicates' function as well as by handwork. Following paper selection by two independent researchers, 15 studies were then thoroughly reviewed. Of these, five studies were excluded, among which two had no control groups ${ }^{25,26}$, one no relation to MTFHD $1^{27}$, and the other two presented data previously published $^{28,29}$. Finally, 10 studies that met the criteria were included in the systematic review (Table 1$)^{10-12,30-36}$ and mathematic data

\section{Table 1. Characteristics of studies included in the systematic review and meta-analysis.}

\begin{tabular}{|c|c|c|c|c|c|c|c|c|c|c|}
\hline \multirow[t]{2}{*}{ No. } & \multirow[t]{2}{*}{ Authors (year) } & \multirow[t]{2}{*}{ Country } & \multirow[t]{2}{*}{$\begin{array}{l}\text { Geographical } \\
\text { location }\end{array}$} & \multirow[t]{2}{*}{ Subjects } & \multirow[t]{2}{*}{$\begin{array}{l}\text { Methods for } \\
\text { genotyping }\end{array}$} & \multicolumn{2}{|c|}{$\begin{array}{l}\text { Sample size of } \\
\text { case/control } \\
\text { group (just for } \\
\text { the patients) }\end{array}$} & \multirow[t]{2}{*}{$\begin{array}{l}\text { Descriptions of } \\
\text { samples from study } \\
\text { participants }\end{array}$} & \multirow[t]{2}{*}{$\begin{array}{l}\text { P for } \\
\text { HWE* of } \\
\text { control } \\
\text { group }\end{array}$} & \multirow[t]{2}{*}{$\begin{array}{l}\text { Whether } \\
\text { included } \\
\text { in meta- } \\
\text { analysis } \\
\text { or not }\end{array}$} \\
\hline & & & & & & case & control & & & \\
\hline 1 & $\begin{array}{l}\text { Mostowska et al. } \\
\text { (2006) }\end{array}$ & Poland & Europe & Mothers & PCR-RFLP/ & 122 & 82 & $\begin{array}{l}\text { The case samples } \\
\text { came from healthy } \\
\text { mothers of NSCL/P } \\
\text { children, while the } \\
\text { control group includes } \\
\text { samples from healthy } \\
\text { mothers of children } \\
\text { without NSCL/P. There } \\
\text { was no difference } \\
\text { between the two } \\
\text { groups in their age, } \\
\text { habit of smoking. }\end{array}$ & $\mathrm{NM}^{\psi}$ & Yes \\
\hline 2 & $\begin{array}{l}\text { Boyles et al. } \\
\text { (2008) }\end{array}$ & Norway & Europe & $\begin{array}{l}\text { Mothers } \\
\text { and } \\
\text { children }\end{array}$ & $\begin{array}{l}\text { MALDI-TOF } \\
\text { MS }^{\xi}\end{array}$ & 573 & 763 & $\begin{array}{l}377 \text { cases were CL/P } \\
\text { and } 196 \text { cases CPO. } \\
\text { Most mothers in } \\
\text { the case group use } \\
\text { supplemental folate } \\
\text { during the pregnancy. }\end{array}$ & $\mathrm{NM}^{\psi}$ & No \\
\hline 3 & $\begin{array}{l}\text { Mills et al. } \\
(2008)\end{array}$ & Ireland & Europe & $\begin{array}{l}\text { Mothers, } \\
\text { fathers } \\
\text { and } \\
\text { children }\end{array}$ & PCR-RFLP $\gamma$ & 1030 & 1000 & $\begin{array}{l}536 \text { were CLP } \\
\text { consisted of } 494 \text { cases } \\
\text { with isolated defects } \\
23 \text { with one additional } \\
\text { defect, } 18 \text { with multiple } \\
\text { defects, and one with } \\
\text { Pierre Robin. } 426 \text { cases } \\
\text { with CPO consisted of } \\
321 \text { isolated defects, } \\
15 \text { with one additional } \\
\text { defect, } 21 \text { with multiple } \\
\text { defects, and } 69 \text { with } \\
\text { Pierre Robin Sequence. }\end{array}$ & 0.03 & Yes \\
\hline 4 & $\begin{array}{l}\text { Bufalino et al. } \\
\text { (2010) }\end{array}$ & Brazil & South America & Mothers & PCR-RFLP' & 106 & 184 & $\begin{array}{l}\text { Mothers who smoke, } \\
\text { drink and use anti- } \\
\text { hypertensives and } \\
\text { drugs that could } \\
\text { potentially impair the } \\
\text { function of folic acids } \\
\text { were not included in } \\
\text { this study. }\end{array}$ & 0.66 & Yes \\
\hline
\end{tabular}




\begin{tabular}{|c|c|c|c|c|c|c|c|c|c|c|}
\hline \multirow[t]{2}{*}{ No. } & \multirow[t]{2}{*}{ Authors (year) } & \multirow[t]{2}{*}{ Country } & \multirow[t]{2}{*}{$\begin{array}{l}\text { Geographical } \\
\text { location }\end{array}$} & \multirow[t]{2}{*}{ Subjects } & \multirow[t]{2}{*}{$\begin{array}{l}\text { Methods for } \\
\text { genotyping }\end{array}$} & \multicolumn{2}{|c|}{$\begin{array}{l}\text { Sample size of } \\
\text { case/control } \\
\text { group (just for } \\
\text { the patients) }\end{array}$} & \multirow[t]{2}{*}{$\begin{array}{l}\text { Descriptions of } \\
\text { samples from study } \\
\text { participants }\end{array}$} & \multirow[t]{2}{*}{$\begin{array}{l}\text { P for } \\
\text { HWE* of } \\
\text { control } \\
\text { group }\end{array}$} & \multirow[t]{2}{*}{$\begin{array}{l}\text { Whether } \\
\text { included } \\
\text { in meta- } \\
\text { analysis } \\
\text { or not }\end{array}$} \\
\hline & & & & & & case & control & & & \\
\hline 5 & $\begin{array}{l}\text { Mostowska et al. } \\
\text { (2010) }\end{array}$ & Poland & Europe & Children & PCR-RFLP & 174 & 176 & $\begin{array}{l}\text { The patients with clefts } \\
\text { palate only (CPO) were } \\
\text { excluded because the } \\
\text { researchers thought } \\
\text { the pathogenesis of } \\
\text { NSCL/P and the CPO } \\
\text { was different. }\end{array}$ & 0.11 & Yes \\
\hline 6 & Li et al. (2013) & China & Asian & Children & PCR-RFLP/ & 187 & 157 & $\begin{array}{l}\text { The patients in the case } \\
\text { group consisted of } 126 \\
\text { boys and } 61 \text { girls. }\end{array}$ & 0.89 & Yes \\
\hline 7 & Yuan (2013) & China & Asian & $\begin{array}{l}\text { Mothers, } \\
\text { fathers } \\
\text { and } \\
\text { children }\end{array}$ & PCR-RFLP & 150 & 150 & $\begin{array}{l}68 \text { CLO and } 82 \text { CLP } \\
\text { were enrolled in the } \\
\text { case group. }\end{array}$ & 0.92 & Yes \\
\hline 8 & $\begin{array}{l}\text { Zhao et al. } \\
\text { (2013) }\end{array}$ & China & Asian & Children & PCR-RFLP/ & 294 & 126 & $\begin{array}{l}\text { There were } 191 \mathrm{CLP} \\
\text { and } 103 \mathrm{CPO} \text { in the } \\
\text { patients group. }\end{array}$ & 0.08 & Yes \\
\hline 9 & $\begin{array}{l}\text { de Aquino et al. } \\
\text { (2013) }\end{array}$ & Brazil & South America & $\begin{array}{l}\text { Mothers, } \\
\text { fathers } \\
\text { and } \\
\text { children }\end{array}$ & $\begin{array}{l}\text { Real-Time } \\
\text { PCR }\end{array}$ & 181 & 478 & $\begin{array}{l}\text { Patients with clefts } \\
\text { palate only (CPO) were } \\
\text { excluded. } 65 \text { clefts lip } \\
\text { only (CLO) and } 116 \\
\text { clefts lip and palate } \\
\text { (CLP) were included in } \\
\text { this study, consisting } \\
\text { of } 101 \text { males and } 80 \\
\text { females. }\end{array}$ & $\mathrm{NM}^{\psi}$ & No \\
\hline 10 & $\begin{array}{l}\text { Murthy et al. } \\
\text { (2014) }\end{array}$ & India & Asian & Children & PCR-RFLP & 142 & 141 & $\begin{array}{l}\text { There were } 123 \text { CLP } \\
\text { and } 19 \mathrm{CPO} \text { in the case } \\
\text { group. }\end{array}$ & 0.94 & Yes \\
\hline
\end{tabular}

HWE*: Hardy-Weinberg equilibrium.

$N M^{\psi}$ : Not mentioned in the study.

PCR-RFLPr: PCR-restriction fragment length polymorphism.

MALDI-TOF MS

from eight studies were used for reference to carry out the metaanalysis $^{10-12,31-33,35,36}$. The selection process is shown in Figure 1.

\section{Study characteristics}

Eventually, all 10 studies containing 6216 samples (2959 cases and 3257 controls) were analyzed in our review. The characteristics of every study can be seen in Table 1 . To summarize briefly, there were four studies from European groups, four from Asian groups and two from South American groups, among which two studies focused on the genotype of patients' mothers only, four on children's genotype only and four on both of them. PCR-restriction fragment length polymorphism (PCR-RFLP) was the major method of genotyping, while other techniques had been used as well.

Association between MTHFD1 polymorphism rs2236225 (c.1958G >A) and NSCL/P susceptibility

The association between MTHFD1 polymorphism rs2236225 (c.1958G >A) and NSCL/P susceptibility was analyzed through a meta-analysis and qualitative analysis. In the meta-analysis, since significant heterogeneity had been identified by Q-test and $\mathrm{I}^{2}$ statistic 

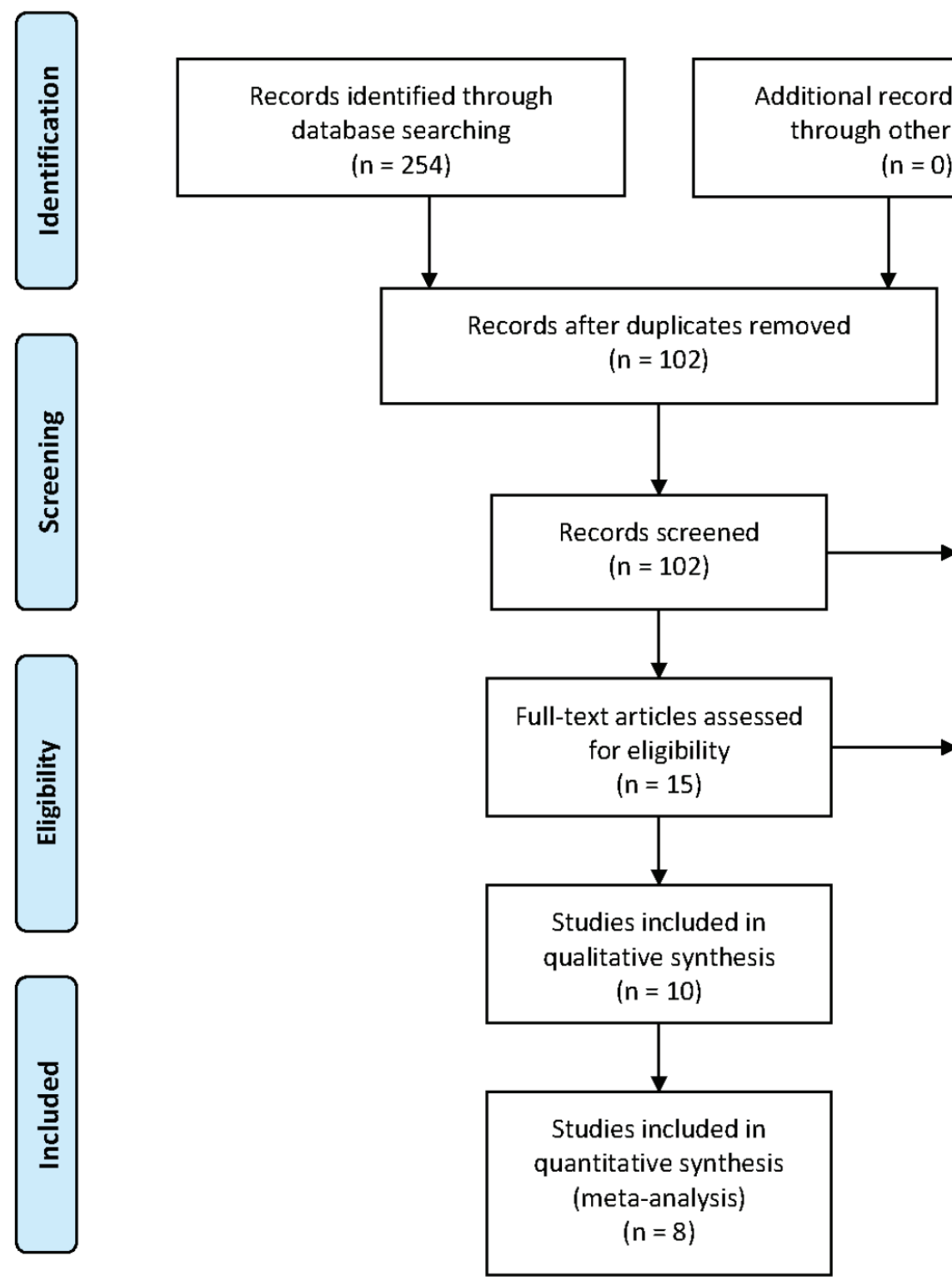

Records excluded $(n=87)$

Figure 1. Flow chart showing study selection in the systematic and meta-analysis.

in every genetic model, the random effect models were used. Overall, a significant association was not found in any genetic model (A versus $\mathrm{G}: \mathrm{OR}=1.02,95 \% \mathrm{CI} 0.86-1.21, \mathrm{P}_{\mathrm{H}}=0.010$, Figure 2; AG versus GG: $\mathrm{OR}=0.97,95 \%$ CI $0.75-1.26, \mathrm{P}_{\mathrm{H}}=0.019$, Figure $3 \mathrm{~A} ; \mathrm{AA}$ versus GG: $\mathrm{OR}=1.07,95 \% \mathrm{CI} 0.70-1.65, \mathrm{P}_{\mathrm{H}}=0.005$, Figure $3 \mathrm{~B}$; $\mathrm{AA}+\mathrm{AG}$ versus $\mathrm{GG}: \mathrm{OR}=1.00,95 \% \mathrm{CI} 0.76-1.31, \mathrm{P}_{\mathrm{H}}=0.006$, Figure 3C; AA versus AG + GG: OR $=1.05,95 \%$ CI $0.71-1.53$, $\mathrm{P}_{\mathrm{H}}=0.014$, Figure 3D). On the other hand, no association was found in the genotypes of children, mothers or fathers in the qualitative analysis ${ }^{30,34}$.
Next we conducted the subgroup analysis using allelic A versus $G$ model according to the location of geography and subjects (mothers or children). It turned out that there was no significant difference between Asian $\left(\mathrm{OR}=1.03,95 \%\right.$ CI $\left.0.75-1.40, \mathrm{P}_{\mathrm{H}}=0.003\right)$ or non-Asian population $\left(\mathrm{OR}=1.06,95 \%\right.$ CI $\left.0.86-1.30, \mathrm{P}_{\mathrm{H}}=0.118\right)$. However, a higher degree of heterogeneity was observed in the Asian countries compared to non-Asian countries (Figure 4A). A similar result was observed in the subgroup analysis between mothers and children. The heterogeneity was much higher in the children group $\left(\mathrm{OR}=0.99,95 \% \mathrm{CI} 0.72-1.36, \mathrm{P}_{\mathrm{H}}=0.001\right)$ than in the 
mothers' group $\left(\mathrm{OR}=1.11,95 \% \mathrm{CI} 0.98-1.27, \mathrm{P}_{\mathrm{H}}=0.630\right)$, while no significant difference was observed in both groups (Figure 4B).

\section{Sensitivity analysis and publication bias}

To access the influence of each individual study on the pooled ORs, a sensitivity analysis was performed by omitting each study at a time. The results of sensitivity suggests that no individual study affects the pooled ORs of the associations between MTHFD1 polymorphism rs2236225 (c.1958G>A) and NSCL/P risk under allelic model (Figure 5).

We used the Begg's funnel plot and Egger's regression test (both used the allelic A versus $\mathrm{G}$ model) to estimate the publication bias. Our results indicate that there is no significant publication bias both in the symmetry of Begg's funnel plot $(\mathrm{P}=0.711$, Figure 6$)$ and Egger's regression test $(\mathrm{P}=0.746)$.

\section{Discussion}

$\mathrm{CL} / \mathrm{P}$ is one of the most common facial malformations, affecting approximately $1.7 / 1000$ people around the world with ethnic and geographic variation ${ }^{1}$. Although $\mathrm{CL} / \mathrm{P}$ is not considered one of the major causes of infant mortality, individuals affected by $\mathrm{CL} / \mathrm{P}$ it may have difficulties in feeding, speaking, difficult social integration ${ }^{4}$. Approximately $70 \%$ of $\mathrm{CL} / \mathrm{P}$ cases are considered to be non-syndromic ${ }^{37,38}$, and their susceptibility has been linked to the expression of various candidate genes through twin studies, familial clustering studies and genome-wide studies ${ }^{39}$.

Recent studies suggest that using folic acid could reduce the rates of oral clefts ${ }^{6,7}$. Some genes involved in the metabolism of folic acid such as MTHFR ${ }^{8,9}$, MTR $^{40}$, and MTRR ${ }^{41}$ have been identified. MTHFD1, a crucial gene associated with three sequential enzymatic reactions among 5,10-methylenetetrahydrofolate, 5,10-methenyltetrahydrofolate, 10-formyltetrahydrofolate, tetrahydrofolate, might play a potential role in $\mathrm{NSCL} / \mathrm{P}^{10}$. However, controversial results about the MTHFD1 polymorphism rs2236225 (c.1958G>A) have been reported in different articles ${ }^{10,12}$.

In this systematic review, 10 independent case-control studies were included (eight studies for meta-analysis and two studies qualitatively

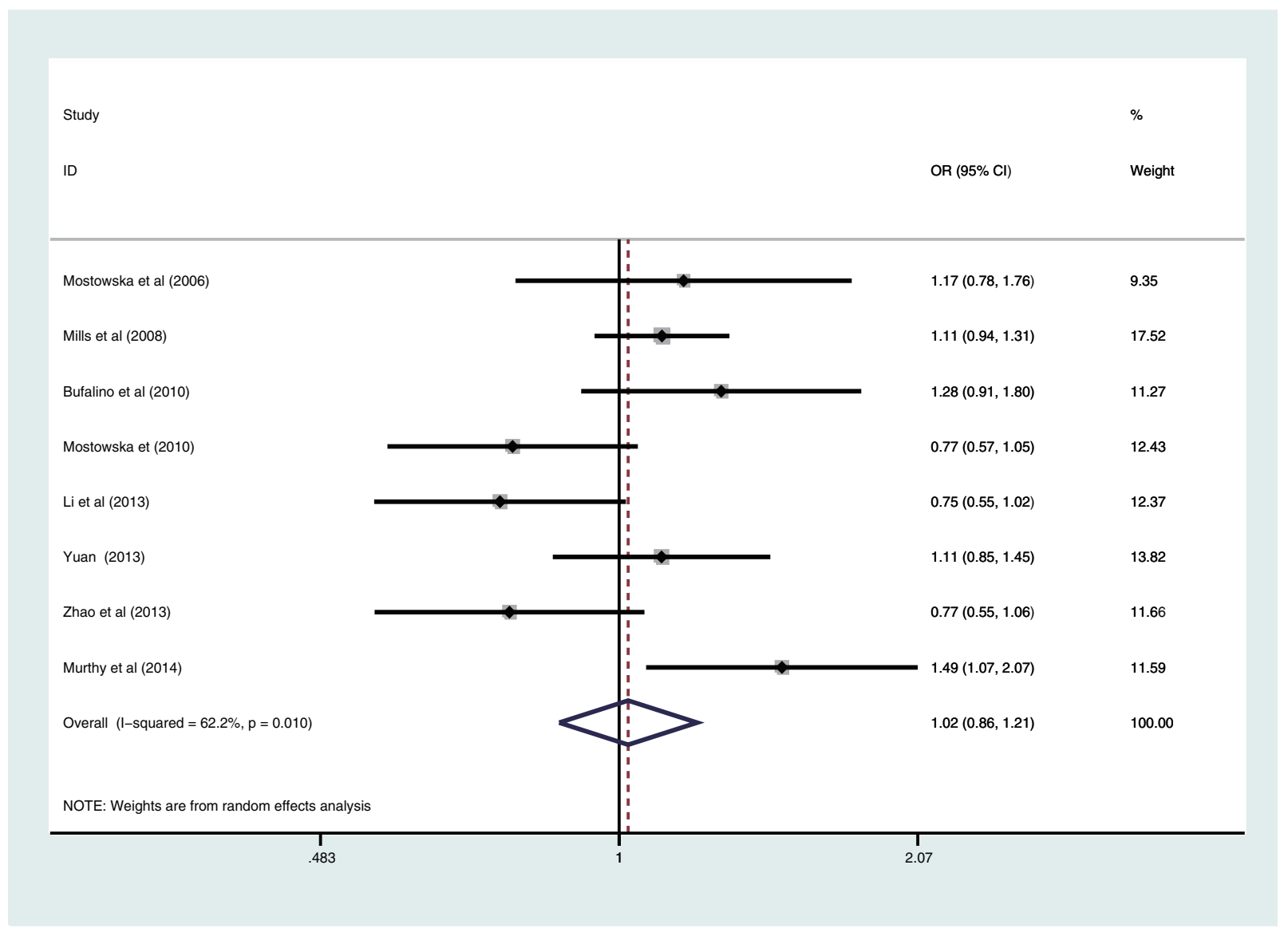

Figure 2. Forest plot of allelic comparison of MTHFD1 polymorphism rs2236225 (c.1958G>A) for overall comparison (A versus G). 
A

Study

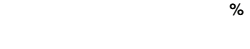

OR $(95 \% \mathrm{Cl})$

Weight

Mills et al (2008)

Bufalino et al (2010)

Mostowska et (2010)

Li et al (2013)

Yuan (2013)

Zhao (2013)

Murthy et al (2014)

Overall (I-squared $=60.3 \%, p=0.019$ )

NOTE: Weights are from random effects analysis

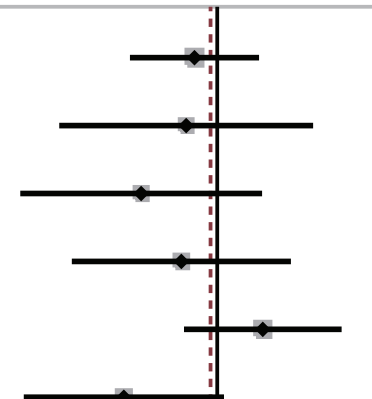

$0.91(0.69,1.20)$

$0.88(0.51,1.51)$

$0.86(0.54,1.37)$

$1.22(0.87,1.70)$

$0.67(0.44,1.03)$

$2.44(1.32,4.51) \quad 10.38$

$0.97(0.75,1.26) \quad 100.00$

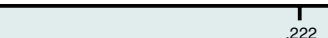

$\underset{4.51}{1}$

B

Study

OR $(95 \% \mathrm{Cl})$

Weight

Mills et al (2008)

Bufalino et al (2010)

Mostowska et (2010)

Li et al (2013)

Yuan (2013)

Zhao (2013)

Murthy et al (2014)

Overall (I-squared $=67.9 \%, p=0.005)$
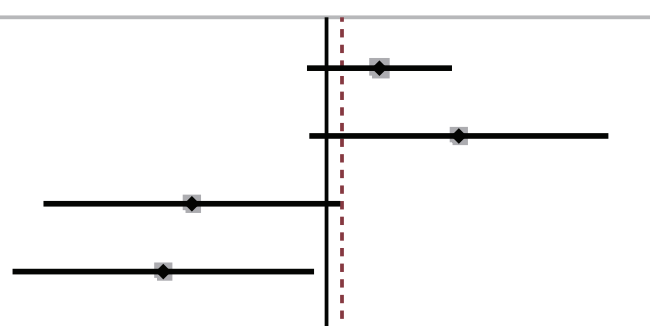

$1.27(0.91,1.77)$

19.71

$1.83(0.92,3.62) \quad 14.32$

$0.54(0.27,1.06) \quad 14.40$

$0.47(0.24,0.94) \quad 14.24$

$1.35(0.64,2.83) \quad 13.49$

$0.70(0.25,1.96) \quad 9.88$

$2.45(1.21,4.97) \quad 13.96$

$1.07(0.70,1.65) \quad 100.00$

NOTE: Weights are from random effects analysis 
C

Study

ID

OR $(95 \% \mathrm{Cl}) \quad$ Weight

\begin{tabular}{|c|c|c|}
\hline Mills et al (2008) & $1.00(0.77,1.30)$ & 18.49 \\
\hline Bufalino et al (2010) & $1.08(0.65,1.79)$ & 12.58 \\
\hline Mostowska et (2010) & $0.68(0.41,1.11)$ & 12.71 \\
\hline Li et al (2013) & $0.76(0.48,1.19)$ & 13.86 \\
\hline Yuan (2013) & $1.26(0.91,1.75)$ & 16.87 \\
\hline Zhao (2013) & $0.67(0.44,1.02)$ & 14.56 \\
\hline Murthy et al (2013) & $2.44(1.36,4.40)$ & 10.93 \\
\hline Overall $(I-$ squared $=67.0 \%, p=0.006)$ & $1.00(0.76,1.31)$ & 100.00 \\
\hline NOTE: Weights are from random effects analysis & & \\
\hline
\end{tabular}

D

Study

ID

OR $(95 \%$ Cl)

Weight

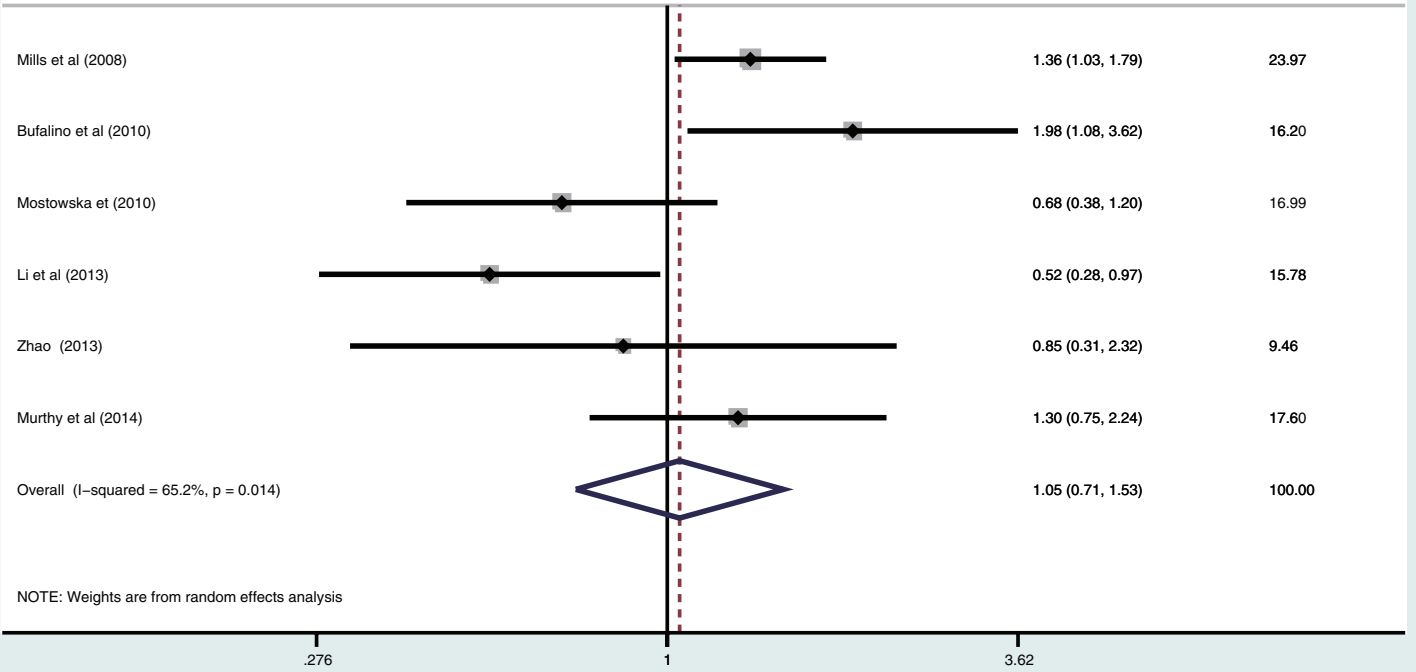

Figure 3. Forest plot of heterozygote, homozygote, dominant and recessive model comparison of MTHFD1 polymorphisms rs2236225 (c.1958G $>$ A) for overall comparison. (A) Heterozygote model, AG versus GG. (B) Homozygote model, AA versus GG. (C) Dominant model, $A A+A G$ versus $G G$. (D) Recessive model, $A A$ versus $A G+G G$. 


\section{A}

Study

ID
$\%$
non-Asian countries

Mostowska et al (2006)

Mills et al (2008)

Bufalino et al (2010)

Mostowska et (2010)

Subtotal $(I-$ squared $=48.9 \%, p=0.118)$

Asian countries

Li et al (2013)

Yuan (2013)

Yuan (2013)

Zhao et al (2013)

Murthy et al (2014)

Subtotal $(I-$ squared $=75.6 \%, p=0.003)$

Overall (I-squared $=64.6 \%, p=0.004$ )

NOTE: Weights are from random effects analysis
OR $(95 \% \mathrm{Cl}) \quad$ Weight

$1.17(0.78,1.76) \quad 9.05$

$1.11(0.94,1.31) \quad 15.57$

$1.28(0.91,1.80) \quad 10.68$

$0.77(0.57,1.05) \quad 11.63$

$1.06(0.86,1.30) \quad 46.92$

$0.75(0.55,1.02) \quad 11.59$

$1.51(1.04,2.20) \quad 9.88$

$0.91(0.62,1.34) \quad 9.67$

$0.77(0.55,1.06) \quad 11.00$

$1.49(1.07,2.07) \quad 10.94$

$1.03(0.75,1.40) \quad 53.08$

$1.04(0.87,1.24) \quad 100.00$

B

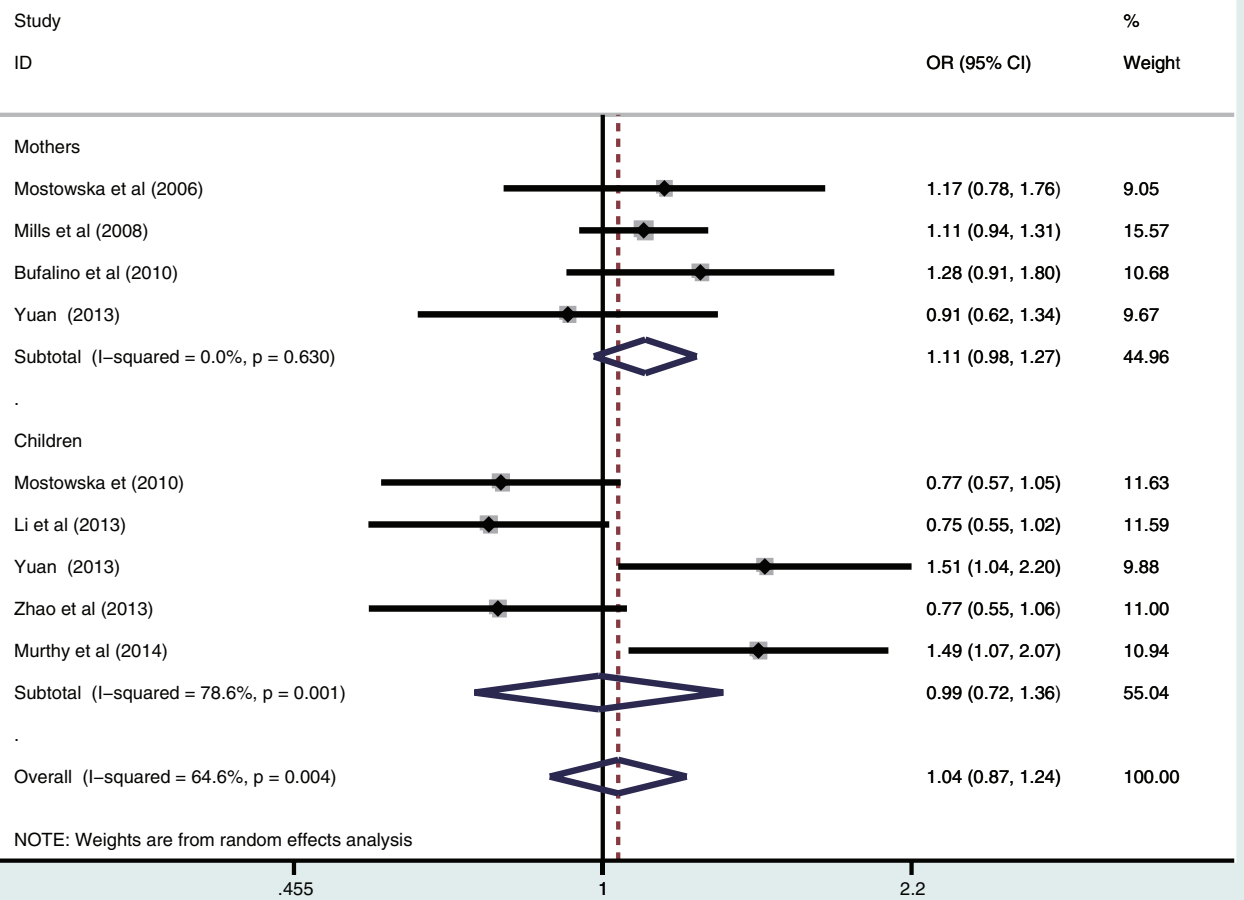

Figure 4. Subgroup analysis by locations of geography $(\mathbf{A})$ and subjects $(\mathbf{B})$ under allelic comparison of MTHFD1 polymorphism rs2236225 (c. 1958G >A). 
Meta-analysis random-effects estimates (exponential form)

Study ommited

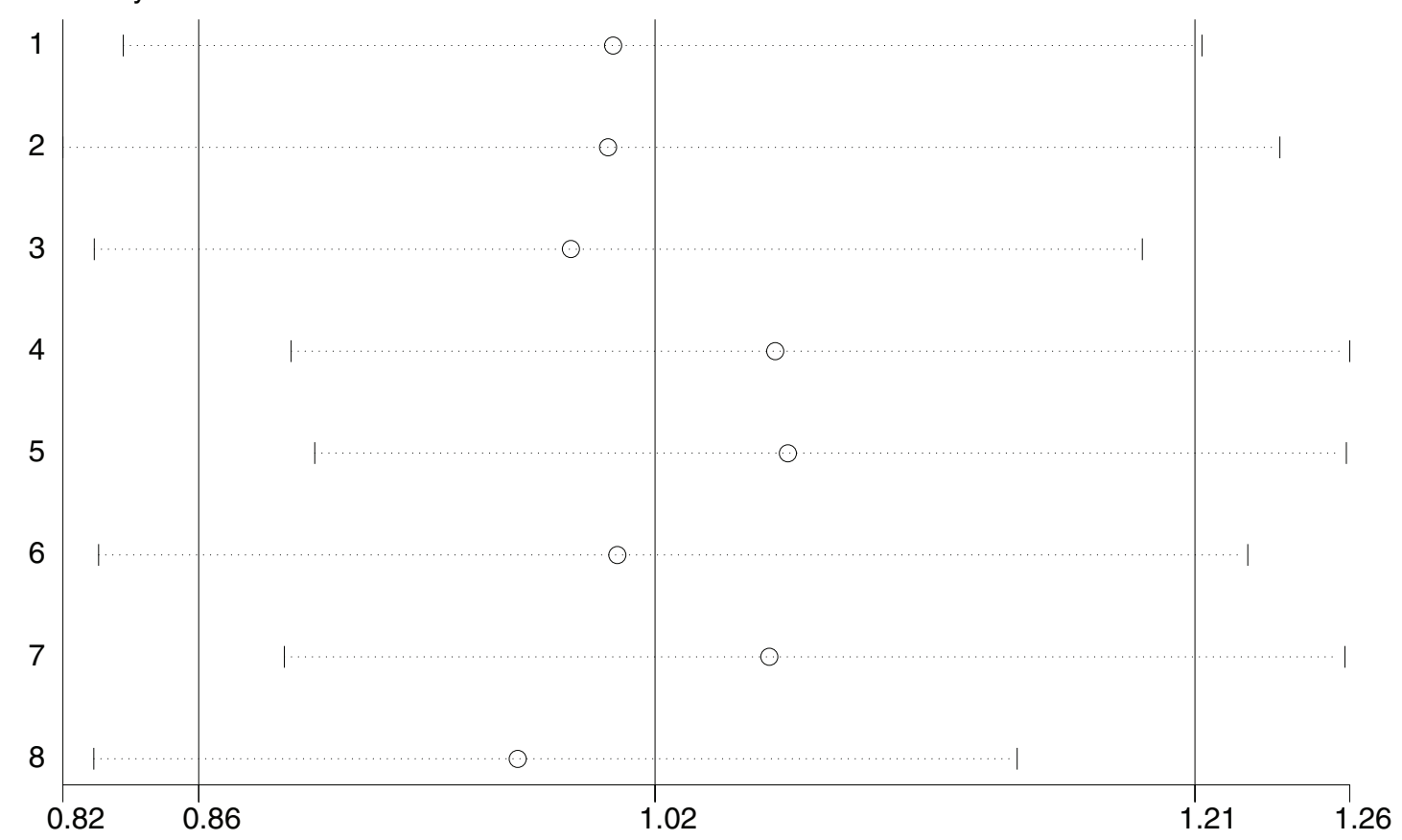

Figure 5. Sensitivity analysis of the association between MTHFD1 polymorphism rs2236225 (c.1958G>A) and susceptibility to NSCL/P under allelic model (A versus $\mathrm{G})$.

Begg's funnel plot with pseudo 95\% confidence limits

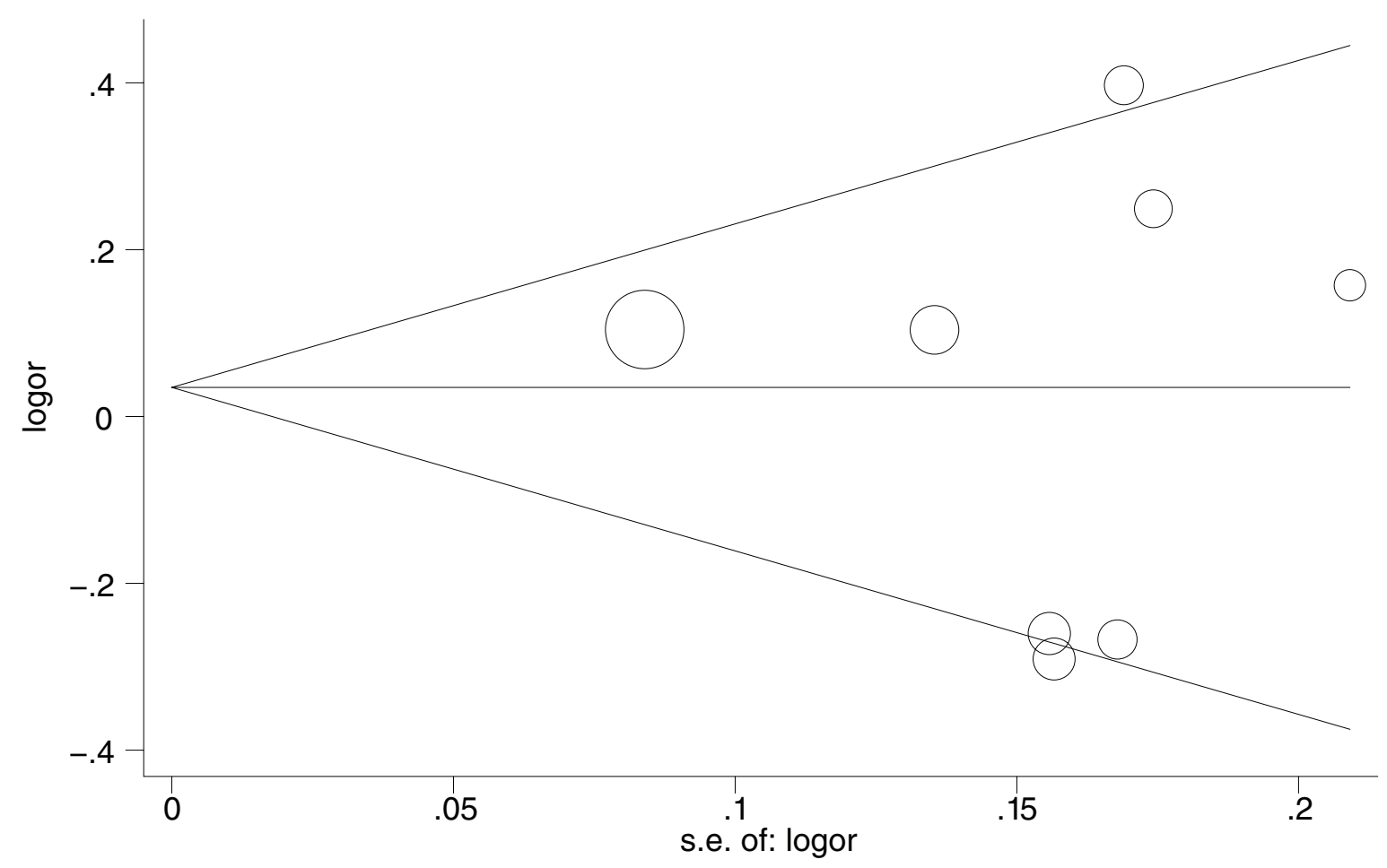

Figure 6. Begg's funnel plot of the association between MTHFD1 polymorphism rs2236225 (c.1958G>A) and the susceptibility to NSCL/P under allelic model (A versus $G$ ). 
analyzed) containing 6216 samples (2959 cases and 3257 controls). All the eligible studies of meta-analysis and qualitative analysis showed no significant association of MTHFD1 rs2236225 to the risk of NSCL/P, whether in the whole analysis of five model (A versus G, AG versus $\mathrm{GG}, \mathrm{AA}$ versus $\mathrm{GG}, \mathrm{AA}+\mathrm{AG}$ versus $\mathrm{GG}$, AA versus $\mathrm{AG}+\mathrm{GG}$ ) or in the subgroup of subjects (mothers or children) and the location of geography (non-Asian countries or Asian countries). Meanwhile, high heterogeneity was observed, which might be the reason for the genetic drift and natural selection among different ethnic groups ${ }^{42}$. Also, small sample size of different studies might be a possible reason for the disparate results. Our findings suggest that the MTHFD1 polymorphism rs2236225 (c.1958G>A) might not be an appropriate biomarker in predicting the susceptibility of an individual to NSCL/P.

Some limitations of this systematic review and meta-analysis should be noted. Firstly, the choice of retrospective studies has its own limitations, as we may encounter selection bias and influence the results of our analysis ${ }^{43}$. However, a bigger size of cohort study cannot be conducted easily because of the relatively low morbidity ${ }^{44}$. Secondly, only 10 studies were included in our review, a small sample size that might not provide sufficient evidence to estimate the connections between the MTHFD1 polymorphisms and the risk of NSCL/P.

NSCL/P is also associated with gene-gene and gene-environment interactions ${ }^{45}$. Although no correlation was observed between MTFHD1 polymorphism rs2236225 (c.1958G >A) and the risk of
NSCL/P, in view of MTFHD1 gene's key role in folic acid metabolism, we cannot draw a definite conclusion that there is no association between MTFHD1 and NSCL/P's susceptibility. The use of larger sample size studies, different techniques and considering gene-gene or gene-environment interactions should be explored in future investigations.

\section{Author contributions}

H Zhao, F Chen, J Lin were responsible for study conception and design of the study. H Zhao, J Zhang, M Zhang acquired the data. H, Zhao, F Chen F, Deng, L Zheng, H Zheng analyzed the data. $\mathrm{H}$ Zhao and J Zhang wrote the main manuscript text. Prof. J Lin and Prof. F Chen had full access to all of the data in this review and take responsibility for the integrity of the data and the accuracy of the data analysis. All authors have agreed to the final content of the manuscript.

\section{Competing interests}

No competing interests were disclosed.

\section{Grant information}

This work was supported by grants 81200762 from National Natural Science Foundation of China; Program for the National Clinical Key Subject, Natural Science Foundation of China (81271183, 81470772); the Medical Scientific Research Project of Chongqing (20141013).

\section{Supplementary materials}

\begin{tabular}{|l|l|}
\hline Table S1. Typical search terms used in Pubmed. \\
\hline$\# 1$ & cleft lip \\
\hline$\# 2$ & cleft palate \\
\hline$\# 3$ & cleft lip and palate \\
\hline \#4 & cleft lip and/or palate \\
\hline$\# 5$ & CLP \\
\hline$\# 6$ & CL/P \\
\hline$\# 7$ & Oral facial cleft \\
\hline \#8 & OFC \\
\hline$\# 9$ & methylenetetrahydrofolate dehydrogenase (NADP+ dependent) 1 \\
\hline$\# 10$ & methenyltetrahydrofolate cyclohydrolase formyltetrahydrofolate synthetase \\
\hline$\# 11$ & MTHFD1 \\
\hline \#12 & MTHFD \\
\hline$\# 13$ & MTHFC \\
\hline$\# 14$ & \#1 OR \#2 OR \#3 OR \#4 OR \#5 OR \#6 OR \#7 OR \#8 \\
\hline \#15 & \#9 OR \#10 OR \#11 OR \#12 OR \#13 \\
\hline \#16 & \#14 AND \#15 \\
\hline
\end{tabular}


Table S2. Scale for methodological quality assessment.

\begin{tabular}{|l|c|}
\hline Items & Score \\
\hline 1. Representative cases & \\
\hline NSCL/P diagnosed by acknowledged criteria. & 2 \\
\hline Mentioned the diagnosed criteria but not described specifically. & 1 \\
\hline Not Mentioned. & 0 \\
\hline 2. Source of controls & \\
\hline Population or community-based & 2 \\
\hline Hospital-based & 1 \\
\hline Not described & 0 \\
\hline 3. Sample size & \\
\hline$>300$ & 2 \\
\hline 150-300 & 1 \\
\hline$<150$ & 0 \\
\hline 4. Hardy-Weinberg equilibrium (HWE) & 1 \\
\hline Hardy-Weinberg equilibrium in control group & 0 \\
\hline Hardy-Weinberg disequilibrium in control group
\end{tabular}

Table S3. PRISMA checklist used for protocol (available at http://www.prisma-statement.org/statement.htm).

\begin{tabular}{|c|c|c|c|}
\hline Section/topic & \# & Checklist item & $\begin{array}{l}\text { Reported on } \\
\text { page \# }\end{array}$ \\
\hline \multicolumn{4}{|l|}{ Title } \\
\hline Title & 1 & Identify the report as a systematic review, meta-analysis, or both. & 1 \\
\hline \multicolumn{4}{|l|}{ Abstract } \\
\hline Structured summary & 2 & $\begin{array}{l}\text { Provide a structured summary including, as applicable: background; objectives; } \\
\text { data sources; study eligibility criteria, participants, and interventions; study } \\
\text { appraisal and synthesis methods; results; limitations; conclusions and implications } \\
\text { of key findings; systematic review registration number. }\end{array}$ & $2 \sim 3$ \\
\hline \multicolumn{4}{|l|}{ Introduction } \\
\hline Rationale & 3 & Describe the rationale for the review in the context of what is already known. & 4 \\
\hline Objectives & 4 & $\begin{array}{l}\text { Provide an explicit statement of questions being addressed with reference to } \\
\text { participants, interventions, comparisons, outcomes, and study design (PICOS). }\end{array}$ & 5 \\
\hline \multicolumn{4}{|l|}{ Methods } \\
\hline $\begin{array}{l}\text { Protocol and } \\
\text { registration }\end{array}$ & 5 & $\begin{array}{l}\text { Indicate if a review protocol exists, if and where it can be accessed (e.g., Web } \\
\text { address), and, if available, provide registration information including registration } \\
\text { number. }\end{array}$ & none \\
\hline Eligibility criteria & 6 & $\begin{array}{l}\text { Specify study characteristics (e.g., PICOS, length of follow-up) and report } \\
\text { characteristics (e.g., years considered, language, publication status) used as } \\
\text { criteria for eligibility, giving rationale. }\end{array}$ & $5 \sim 6$ \\
\hline Information sources & 7 & $\begin{array}{l}\text { Describe all information sources (e.g., databases with dates of coverage, contact } \\
\text { with study authors to identify additional studies) in the search and date last } \\
\text { searched. }\end{array}$ & 5 \\
\hline Search & 8 & $\begin{array}{l}\text { Present full electronic search strategy for at least one database, including any } \\
\text { limits used, such that it could be repeated. }\end{array}$ & Table S1 \\
\hline Study selection & 9 & $\begin{array}{l}\text { State the process for selecting studies (i.e., screening, eligibility, included in } \\
\text { systematic review, and, if applicable, included in the meta-analysis). }\end{array}$ & $5 \sim 6$ \\
\hline $\begin{array}{l}\text { Data collection } \\
\text { process }\end{array}$ & 10 & $\begin{array}{l}\text { Describe method of data extraction from reports (e.g., piloted forms, } \\
\text { independently, in duplicate) and any processes for obtaining and confirming data } \\
\text { from investigators. }\end{array}$ & $5 \sim 6$ \\
\hline
\end{tabular}




\begin{tabular}{|c|c|c|c|}
\hline Section/topic & $\#$ & Checklist item & $\begin{array}{l}\text { Reported on } \\
\text { page \# }\end{array}$ \\
\hline Data items & 11 & $\begin{array}{l}\text { List and define all variables for which data were sought (e.g., PICOS, funding } \\
\text { sources) and any assumptions and simplifications made. }\end{array}$ & $5 \sim 6$ \\
\hline $\begin{array}{l}\text { Risk of bias in } \\
\text { individual studies }\end{array}$ & 12 & $\begin{array}{l}\text { Describe methods used for assessing risk of bias of individual studies (including } \\
\text { specification of whether this was done at the study or outcome level), and how this } \\
\text { information is to be used in any data synthesis. }\end{array}$ & 6 and Table S2 \\
\hline Summary measures & 13 & State the principal summary measures (e.g., risk ratio, difference in means). & $6 \sim 7$ \\
\hline Synthesis of results & 14 & $\begin{array}{l}\text { Describe the methods of handling data and combining results of studies, if done, } \\
\text { including measures of consistency }\left(\text { e.g., }\left.\right|^{2}\right) \text { for each meta-analysis. }\end{array}$ & $6 \sim 7$ \\
\hline $\begin{array}{l}\text { Risk of bias across } \\
\text { studies }\end{array}$ & 15 & $\begin{array}{l}\text { Specify any assessment of risk of bias that may affect the cumulative evidence } \\
\text { (e.g., publication bias, selective reporting within studies). }\end{array}$ & $6 \sim 7$ \\
\hline Additional analyses & 16 & $\begin{array}{l}\text { Describe methods of additional analyses (e.g., sensitivity or subgroup analyses, } \\
\text { meta-regression), if done, indicating which were pre-specified. }\end{array}$ & 7 \\
\hline \multicolumn{4}{|l|}{ Results } \\
\hline Study selection & 17 & $\begin{array}{l}\text { Give numbers of studies screened, assessed for eligibility, and included in the } \\
\text { review, with reasons for exclusions at each stage, ideally with a flow diagram. }\end{array}$ & 8 and Figure 1 \\
\hline Study characteristics & 18 & $\begin{array}{l}\text { For each study, present characteristics for which data were extracted (e.g., study } \\
\text { size, PICOS, follow-up period) and provide the citations. }\end{array}$ & Table 1 \\
\hline $\begin{array}{l}\text { Risk of bias within } \\
\text { studies }\end{array}$ & 19 & $\begin{array}{l}\text { Present data on risk of bias of each study and, if available, any outcome level } \\
\text { assessment (see item 12). }\end{array}$ & 9 10, Table S2 \\
\hline $\begin{array}{l}\text { Results of individual } \\
\text { studies }\end{array}$ & 20 & $\begin{array}{l}\text { For all outcomes considered (benefits or harms), present, for each study: (a) simple } \\
\text { summary data for each intervention group (b) effect estimates and confidence } \\
\text { intervals, ideally with a forest plot. }\end{array}$ & Figure 2 \\
\hline Synthesis of results & 21 & $\begin{array}{l}\text { Present results of each meta-analysis done, including confidence intervals and } \\
\text { measures of consistency. }\end{array}$ & Figure 2 Figure 4 \\
\hline $\begin{array}{l}\text { Risk of bias across } \\
\text { studies }\end{array}$ & 22 & Present results of any assessment of risk of bias across studies (see Item 15). & $\begin{array}{l}\text { Table S2, Figure 5 } \\
\text { Figure } 6\end{array}$ \\
\hline Additional analysis & 23 & $\begin{array}{l}\text { Give results of additional analyses, if done (e.g., sensitivity or subgroup analyses, } \\
\text { meta-regression [see Item 16]). }\end{array}$ & Figure 5 Figure 6 \\
\hline \multicolumn{4}{|l|}{ Discussion } \\
\hline Summary of evidence & 24 & $\begin{array}{l}\text { Summarize the main findings including the strength of evidence for each main } \\
\text { outcome; consider their relevance to key groups (e.g., healthcare providers, } \\
\text { users, and policy makers). }\end{array}$ & $11 \sim 12$ \\
\hline Limitations & 25 & $\begin{array}{l}\text { Discuss limitations at study and outcome level (e.g., risk of bias), and at review-level } \\
\text { (e.g., incomplete retrieval of identified research, reporting bias). }\end{array}$ & 12 \\
\hline Conclusions & 26 & $\begin{array}{l}\text { Provide a general interpretation of the results in the context of other evidence, and } \\
\text { implications for future research. }\end{array}$ & 13 \\
\hline \multicolumn{4}{|l|}{ Funding } \\
\hline Funding & 27 & $\begin{array}{l}\text { Describe sources of funding for the systematic review and other support (e.g., } \\
\text { supply of data); role of funders for the systematic review. }\end{array}$ & 15 \\
\hline
\end{tabular}


1. Mossey PA, Little J, Munger RG, et al.: Cleft lip and palate. Lancet. 2009; 374(9703): 1773-85.

PubMed Abstract | Publisher Full Text

2. Wehby GL, Goco N, Moretti-Ferreira D, et al.: Oral cleft prevention program (OCPP). BMC Pediatr. 2012; 12: 184

PubMed Abstract | Publisher Full Text | Free Full Text

3. Mossey PA, Shaw WC, Munger RG, et al:: Global oral health inequalities: challenges in the prevention and management of orofacial clefts and potentia solutions. Adv Dent Res. 2011; 23(2): 247-58.

PubMed Abstract | Publisher Full Text

4. Wehby GL, Cassell $\mathrm{CH}$ : The impact of orofacial clefts on quality of life and healthcare use and costs. Oral Dis. 2010; 16(1): 3-10. PubMed Abstract | Publisher Full Text | Free Full Text

5. Lidral AC, Murray JC: Genetic approaches to identify disease genes for birth defects with cleft lip/palate as a model. Birth Defects Res A Clin Mol Teratol. 2004; 70(12): 893-901.

PubMed Abstract | Publisher Full Text

6. Yazdy MM, Honein MA, Xing J: Reduction in orofacial clefts following folic acid fortification of the U.S. grain supply. Birth Defects Res A Clin Mol Teratol. 2007; 79(1): 16-23.

PubMed Abstract | Publisher Full Text

7. Johnson $\mathrm{CY}$, Little J: Folate intake, markers of folate status and oral clefts: is the evidence converging? Int J Epidemiol. 2008; 37(5): 1041-58. PubMed Abstract | Publisher Full Text

8. Han Y, Pan Y, Du Y, et al:: Methylenetetrahydrofolate reductase C677T and A1298C polymorphisms and nonsyndromic orofacial clefts susceptibility in a southern Chinese population. DNA Cell Biol. 2011; 30(12): 1063-8. PubMed Abstract | Publisher Full Text

9. Murthy J, Gurramkonda VB, Karthik N, et al.: MTHFR C677T and A1298C polymorphisms and risk of nonsyndromic orofacial clefts in a south Indian population. Int J Pediatr Otorhinolaryngol. 2014; 78(2): 339-42. PubMed Abstract | Publisher Full Text

10. Murthy J, Gurramkonda VB, Lakkakula BV: Significant association of MTHFD1 1958G >A single nucleotide polymorphism with nonsyndromic cleft lip and palate in Indian population. Med Oral Patol Oral Cir Bucal. 2014; 19(6): e616-21. PubMed Abstract | Publisher Full Text | Free Full Text

11. Mostowska A, Hozyasz KK, Jagodzinski PP: Maternal MTR genotype contributes to the risk of non-syndromic cleft lip and palate in the Polish population. Clin Genet. 2006; 69(6): 512-7.

PubMed Abstract | Publisher Full Text

12. Yanbo Z, Xinhua L, Xinrong N: Association between rs2236225 polymorphism in MTHFD1 gene and non-syndromic cleft lip with or without cleft palate in Shanxi population. Shi Yong Kou Qiang Yi Xue Za Zhi. 2013; (4): 521-524. Reference Source

13. Cook DJ, Mulrow CD, Haynes RB: Systematic reviews: synthesis of best evidence for clinical decisions. Ann Intern Med. 1997; 126(5): 376-80. PubMed Abstract | Publisher Full Text

14. Moher D, Jones A, Lepage L: Use of the CONSORT statement and quality of reports of randomized trials: a comparative before-and-after evaluation. JAMA. 2001; 285(15): 1992-5.

PubMed Abstract | Publisher Full Text

15. da Costa BR, Cevallos M, Altman DG, et al: Uses and misuses of the STROBE statement: bibliographic study. BMJ Open. 2011; 1(1): e000048. PubMed Abstract | Publisher Full Text | Free Full Text

16. Guo J, Jin M, Zhang M, et al:: A genetic variant in miR-196a2 increased digestive system cancer risks: a meta-analysis of 15 case-control studies. PLoS One. 2012; 7(1): e30585.

PubMed Abstract | Publisher Full Text | Free Full Text

17. Moher D, Liberati A, Tetzlaff J, et al.: Preferred reporting items for systematic reviews and meta-analyses: the PRISMA statement. Ann Intern Med. 2009; 151(4): 264-9, W64. PubMed Abstract | Publisher Full Text

18. Jackson D, White IR, Riley RD: Quantifying the impact of between-study heterogeneity in multivariate meta-analyses. Stat Med. 2012; 31(29): 3805-20. PubMed Abstract | Publisher Full Text | Free Full Text

19. Peters JL, Sutton AJ, Jones DR, et al:: Comparison of two methods to detect publication bias in meta-analysis. JAMA. 2006; 295(6): 676-80. PubMed Abstract | Publisher Full Text

20. Zintzaras E, loannidis JP: HEGESMA: genome search meta-analysis and heterogeneity testing. Bioinformatics. 2005; 21(18): 3672-3. PubMed Abstract | Publisher Full Text

21. Begg $\mathrm{CB}$, Mazumdar M: Operating characteristics of a rank correlation test for publication bias. Biometrics. 1994; 50(4): 1088-101. PubMed Abstract | Publisher Full Text

22. Egger M, Davey G, Smith M, et al.: Bias in meta-analysis detected by a simple, graphical test. BMJ. 1997; 315(7109): 629-34. PubMed Abstract | Publisher Full Text | Free Full Text

23. Li H, Tie K, Hu N, et al:: Association of two polymorphisms rs2910164 in miRNA-146a and rs3746444 in miRNA-499 with rheumatoid arthritis: a metaanalysis. Hum Immunol. 2014; 75(7): 602-8. PubMed Abstract | Publisher Full Text
24. Thomas J, Harden A: Methods for the thematic synthesis of qualitative research in systematic reviews. BMC Med Res Methodol. 2008; 8: 45. PubMed Abstract | Publisher Full Text | Free Full Text

25. Palmieri A, Masiero E, Martinelli M, et al.: The MTHFD1 gene is not involved in cleft lip with or without palate onset among the Italian population. Ann Hum Genet. 2008; 72(Pt 3): 297-9. PubMed Abstract | Publisher Full Text

26. Blanton $\mathrm{SH}$, Henry RR, Yuan Q, et al.: Folate pathway and nonsyndromic cleft lip and palate. Birth Defects Res A Clin Mol Teratol. 2011; 91(1): 50-60. PubMed Abstract | Publisher Full Text | Free Full Text

27. Lu Y, Liu Q, Xu W, et al.: TGFA and IRF6 contribute to the risk of nonsyndromic cleft lip with or without cleft palate in northeast China. PLOS One. 2013; 8(8): e70754.

PubMed Abstract | Publisher Full Text | Free Full Text

28. Li R: Association between genetic polymorphism of MTHFD1 and MTR adn non-syndromic oral cleft with or without cleft palate in Shanxi, China. Shanx Medical University. 2013.

29. Zhao Y: Research of association between rs22362225 polymorphism in MTHFD1 and non-syndromic cleft lip with or without cleft palate in Shanxi population. Shanxi Medical University. 2012

30. Boyles AL, Wilcox AJ, Taylor JA, et al:: Folate and one-carbon metabolism gene polymorphisms and their associations with oral facial clefts. Am J Med Genet A. $2008 ; 146 \mathrm{~A}(4)$ : 440-9.

PubMed Abstract | Publisher Full Text | Free Full Text

31. Mills Jl, Molloy AM, Parle-McDermott A, et al.: Folate-related gene polymorphisms as risk factors for cleft lip and cleft palate. Birth Defects Res $A$ Clin Mol Teratol. 2008; 82(9): 636-643.

PubMed Abstract | Publisher Full Text | Free Full Text

32. Bufalino A, Paranaiba LMR, de Aquino SN, et al:: Maternal polymorphisms in folic acid metabolic genes are associated with nonsyndromic cleft lip and/or palate in the Brazilian population. Birth Defects Res A Clin Mol Teratol. 2010; 88(11): 980-986.

PubMed Abstract | Publisher Full Text

33. Mostowska A, Hozyasz KK, Wojcicki P, et al:: Associations of folate and choline metabolism gene polymorphisms with orofacial clefts. J Med Genet. 2010; 47(12): 809-15.

PublMed Abstract | Publisher Full Text

34. deAquino SN, Hoshi R, Bagordakis E, et al:: MTHFR rs2274976 Polymorphism Is a Risk Marker for Nonsyndromic Cleft Lip with or without Cleft Palate in the Brazilian Population. Birth Defects Res A Clin Mol Teratol. 2014; 100(1): 30-35. PubMed Abstract | Publisher Full Text

35. Li R, Ma X, Nan X: Association between genetic polymorphism of methylenetetrahydrofolate dehydrogenase 1 , mehionine synthase and nonsyndromic cleft lip with or without cleft palate in Shanxi, China. Guo Ji Kou Qiang Yi Xue Za Zhi. 2013; (2): 144-147. Publisher Full Text

36. Yuan G: Nuclear family study of the relationship between MTHFD1, MTR polymorphism and non-syndromic cleft lip with or without cleft palate in Shanxi Province. Shanxi Medical University. 2013.

Reference Source

37. Jones MC: Etiology of facial clefts: prospective evaluation of $\mathbf{4 2 8}$ patients. Cleft Palate J. 1988; 25(1): 16-20.

PubMed Abstract

38. FitzPatrick DR, Raine PA, Boorman JG: Facial clefts in the west of Scotland in the period 1980-1984: epidemiology and genetic diagnoses. J Med Genet. 1994; 31(2): 126-9.

PubMed Abstract | Publisher Full Text | Free Full Text

39. Dixon MJ, Marazita ML, Beaty TH, et al:: Cleft lip and palate: understanding genetic and environmental influences. Nat Rev Genet. 2011; 12(3): 167-78. PubMed Abstract | Publisher Full Text | Free Full Text

40. Bezerra JF, Oliveira GH, Soares CD, et al:: Genetic and non-genetic factors that increase the risk of non-syndromic cleft lip and/or palate development. Oral Dis. 2014; 21(3): 393-9

PubMed Abstract | Publisher Full Text

41. Chorna LB, Akopian HR, Makukh HV, et al.: [Allelic polymorphism of MTHFR, MTR and MTRR genes in patients with cleft lip and/or palate and their mothers]. Tsitol Genet. 2011; 45(3): 51-6. PubMed Abstract

42. Serre D, Montpetit A, Pare G, et al:: Correction of population stratification in large multi-ethnic association studies. PLoS One. 2008; 3(1): e1382. PubMed Abstract | Publisher Full Text | Free Full Text

43. Stroup DF, Thacker SB, Olson CM, et al.: Characteristics of meta-analyses related to acceptance for publication in a medical journal. J Clin Epidemiol. 2001; 54(7): 655-60.

PubMed Abstract | Publisher Full Text

44. Kling RR, Taub PJ, Ye X, et al:: Oral clefting in China over the last decade: 205,679 patients. Plast Reconstr Surg Glob Open. 2014; 2(10): e236. PubMed Abstract | Publisher Full Text | Free Full Text

45. Murray JC: Gene/environment causes of cleft lip and/or palate. Clin Genet 2002; 61(4): 248-56.

PubMed Abstract | Publisher Full Text 


\title{
Open Peer Review
}

\section{Current Peer Review Status:}

\section{Version 1}

Reviewer Report 06 July 2015

https://doi.org/10.5256/f1000research.6892.r9328

(C) 2015 Suazo J. This is an open access peer review report distributed under the terms of the Creative Commons Attribution License, which permits unrestricted use, distribution, and reproduction in any medium, provided the original work is properly cited.

\begin{abstract}
Jose Suazo
Institute for Research in Dental Sciences, Faculty of Dentistry, University of Chile, Santiago, Chile

In general terms, this article contributes to unraveling the complex genetic architecture of NSCL/P. This type of systematic reviews are always relevant due to the fact that they pooled several singles trials, and therefore, the sample sizes have an important increase. However, this article needs some modifications that avoid to be published in its current version:

1. All of the gene acronyms may be written italics.

2. The title says "Is MTHFD1 polymorphisms..." but it refers to only one SNP.

3. The Materials and Method section includes the quality analysis of each paper included in this meta-analysis, but Results section did not mentioned anything about this analysis.

4. The publication bias analysis when $<10$ articles is not statistically resolved (see Egers's paper), so for this meta-analysis it is necessary at least a comment about this issue.

5. The first two paragraph of the Discussion section are almost the same as the Introduction.

6. I think that the Discussion could include a comment about maternal genotype effects in order to explain the negative results of this analysis.
\end{abstract}

Competing Interests: No competing interests were disclosed.

I confirm that I have read this submission and believe that I have an appropriate level of expertise to confirm that it is of an acceptable scientific standard, however I have significant reservations, as outlined above.

Author Response 26 Nov 2015

Feng Chen, Peking University School and Hospital of Stomatology, Peking, China 
Thank you so much for your precious advice. We have studied your comments carefully and revised the manuscript. The point to point responds are listed as following:

1. We have corrected all the inappropriate format of gene acronyms;

2. Our title says "Is MTHFD1 polymorphisms rs 2236225 (c.1958G>A)...", which refers to a specific SNP in accordance with the content;

3. The traditional meta-analysis focuses on the clinical RCTs, which aims to reveal the relevance between specific interruption and clinical effects. A complete assessment standard for the included RCT reports has been widely accepted and used. While our study material is totally different from RCTs thus there is no clear assessment standard to refer. So we do not discuss the quality analysis. But in order to provide the readers an assessment standard we provide the tables 2 in supplementary materials for reference.

4. We agree that the usual method to evaluate publication bias is not suitable for our study because of the limited amount, which reduces the reliability of our conclusion. We have declared that in the discussion of our updated version.

5. Actually the Discussion is an overview of the article, which includes and further explains the content above. While in avoidance of repetition we modified and simplified the first and second paragraph of the Discussion.

6. Two of our included studies only analyzed the maternal genotype, one study reported the mother and children genotype and three took samples from children and their parents. The gene samples from mother were too scarce to be representative and to explain our results. We do recommend more samples from parents in the future studies, which is significant for the early stage diagnose, as the current technology can only diagnose CLP in the midterm even later in the pregnancy.

Competing Interests: No competing interests were disclosed.

Reviewer Report 17 June 2015

https://doi.org/10.5256/f1000research.6892.r8906

(C) $2015 \mathrm{Su}$ J. This is an open access peer review report distributed under the terms of the Creative Commons Attribution License, which permits unrestricted use, distribution, and reproduction in any medium, provided the original work is properly cited.

\section{Jingtan Su}

Center for Craniofacial Molecular Biology, University of Southern California, Los Angeles, CA, USA

Non-syndromic cleft of the lip and/or palate (NSCL/P) is considered closely related to genetic and 
environmental factors. As a key gene in the metabolism of folic acid which is associated to high risk of NSCL/P, methylenetetrahydrofolate dehydrogenase (MTHFD1) polymorphisms rs 2237225 (c. 1958G>A) may be associated with the susceptibility of NSCL/P. However, controversial conclusions on this association have been reported by different groups. This paper conducted a systematic review and meta-analysis of eligible case-control studies which is necessary before we go forward to larger sample size studies.

This paper is scientifically sound, clear and well-organized. However, these following revisions may make it more interesting.

1. Page 6, Figure 1, Eligibility section, the number of full-text articles excluded with reasons should be 5 .

2. The lack of folic acid will result in many health problems such as neural tube defects, macrocytic anemia, mental depress and so on, not only NSCL/P. MTHFD1 is important in the metabolism of folic acid. Why is it suggested that MTHFD1 polymorphisms may be associated with the susceptibility of NSCL/P, but not neural tube defects (Meng et al., 2015) or other diseases (Weiner et al., 2014; Silva et al., 2011)?

3. It is mentioned in the Discussion section that controversial results about the MTHFD1 polymorphism rs2236225 (c. 1958G>A) have been reported in different articles. A brief description about the controversial results and their conclusions will make the discussion more interesting.

4. MTHFR, MTR, AND MTRR which are involved in the metabolism of folic acid are reported to be associated with high risk of NSCL/P. Why MTHFD1 which is also involved in the metabolism of folic acid shows no significant association with susceptibility to NSCL/P? It's due to the sample size or the limit of technique, or it is the truth? A brief discussion on this will be interesting.

Competing Interests: No competing interests were disclosed.

\section{I confirm that I have read this submission and believe that I have an appropriate level of expertise to confirm that it is of an acceptable scientific standard.}

Author Response 26 Nov 2015

Feng Chen, Peking University School and Hospital of Stomatology, Peking, China

Thank you. We have studied your valuable comments and revised the manuscript according to your suggestions. The point to point responds are listed as following:

1. We have corrected the error, thank you;

2. Neural tube defects and NSCL/P is similar in the origin of development, while the different relationship with MTHFD1 may suggest the different pathogenesis. Maybe each part of organ has a specific different folic acid metabolic pathway in their development.

3. We are so glad to follow your advice. In all of the included 8 studies, 7 did not show 
significant difference between the case and control groups. 1 study reported the case group showed closer relationship with MTHFD1 polymorphisms rs 2236225

(c.1958G >A). A brief description of this controversy is also included in this article.

4. All 10 studies containing 6216 samples (2959 cases and 3257 controls) were analyzed in our article. Limited to the size of simple, our result cannot give a certain conclusion about the relationship of MTHFD1 and NSCL/P and won't deny the possibility of an actual relationship. The heterogeneity exists in the research method, sample source area and maternal or children genotypes. The incident rate and clinical manifestation differ in various areas. Different research method would lead to diverse accuracy even controversial conclusion. Thus we are still not sure about the association between MTHFD1 and NSCL/P and further exploration is needed. We also discussed this matter in our article.

Competing Interests: No competing interests were disclosed.

The benefits of publishing with F1000Research:

- Your article is published within days, with no editorial bias

- You can publish traditional articles, null/negative results, case reports, data notes and more

- The peer review process is transparent and collaborative

- Your article is indexed in PubMed after passing peer review

- Dedicated customer support at every stage

For pre-submission enquiries, contact research@f1000.com 